\title{
Algorithm for dental caries risk assessment
}

\author{
Algoritm pentru evaluarea riscului de carie dentară
}

Cristian Funieru
Disciplina de Prevenţie Oro-Dentară, Facultatea de Medicină Dentară, UMF „Carol Davila“,
Bucureşti, România

\begin{abstract}
Introduction. Caries risk assessment in individual patients is mandatory as it becomes a starting point for developing patient-centered preventive strategies. Any method designed for caries risk assessment should be based on the risk and protection factors involved.

Material and method. The first part of this study consists of a fundamental research based on a metaanalysis style study of a number of 128 articles present in the main on-line databases. The other part of the study is dedicated to the development of a mathematical algorithm of dental caries risk.

Results. The caries risk is based on the algorithm presented in this study which takes into account 8 risk or protection factors, their frequency and coefficients being found in the main publications flow and assigned according to an evaluation scale.

Conclusions. Although at first glance it seems to be a simple and easy to apply mathematical formula, this algorithm must be validated in a future and specially designed study before it could be used on a large scale.
\end{abstract}

Keywords: caries, risk, assessment

\section{REZUMAT}

Introducere. Evaluarea riscului de carie dentară este foarte importantă prin prisma necesităţii dezvoltării unor strategii preventive centrate pe individ. Algoritmul oricărei metode de determinare a riscului trebuie să se bazeze în mod obligatoriu pe factorii de risc şi pe cei de protecţie implicaţi.

Materiale şi metodă. Studiul este compus dintr-o parte de cercetare fundamentală bazată pe un studiu, în stilul unei meta-analize, a unui număr de 128 de articole prezente în principalele baze de date de profil. Cealaltă parte a studiului este rezervată dezvoltării unui algoritm matematic al riscului la carie dentară.

Rezultate. Riscul de carie dentară este obţinut prin intermediul unui algoritm care ţine cont de 8 factori de risc sau de protecţie, de frecvenţa cu care ei au fost găsiţi în fluxul principal de publicaţii şi de coeficienţii atribuiţi conform unei scale de valori.

Concluzii. Deşi la prima vedere pare o formulă matematică simplă şi uşor de aplicat, acest algoritm trebuie validat în ideea folosirii lui la scară largă.

Cuvinte cheie: carie, risc, evaluare

\section{INTRODUCERE}

Riscul de carie dentară este important atât prin prisma managementului leziunilor carioase deja existente, cât şi prin dezvoltarea unei strategii preventive personalizate pentru fiecare pacient în parte. Pentru elaborarea unui algoritm de evaluare a riscului de carie dentară trebuie mai întâi cunoscuți factorii de risc implicați (1-7):

- Factorii microbiologici: prezența Streptococului mutans într-un număr ridicat de colonii, precum şi a lactobacililor;
- Alimentația: consumul zilnic de zahăr, consumul de alimente pe timp de noapte, frecvența ridicată a consumului de dulciuri şi de băuturi cu zahăr, forma de prezentare a dulciurilor preferate (dulciuri lipicioase: caramele, jeleuri sau produse de patiserie, ce conțin combinația dizaharide-amidon etc.), buget crescut alocat zilnic pentru dulciuri, ingestia scăzută de magneziu, ingestia crescută de fier, ora înaintată a ultimei mese a zilei etc.;

- Calitatea precară a igienei orale: frecvența periajului (mai rar decât o dată pe zi), vârsta 
târzie de debut a periajului, neutilizarea aței dentare, placa bacteriană prezentă în cantitate crescută în momentul consultației, gradul de inflamație gingivală - valori mari ale indicilor de placă şi de inflamație gingivală -, tipul de periuță folosit, timpul mediu de folosire a periuței peste 6 luni de zile, durata unui periaj dentar manual de sub 3 minute etc.;

- „Baseline“-ul la care se află pacientul în momentul consultației (numărul şi gravitatea leziunilor existente) precum şi timpul scurt de evoluție al acestora spre leziuni avansate (decelat prin anamneză);

- Valorile anormale ale parametrilor salivari: flux salivar scăzut, capacitate scăzută de tamponare, valori scăzute ale $\mathrm{pH}$-ului sau funcționarea insuficientă a sistemelor tampon;

- Absența fluorizărilor în antecedente de orice fel (personale sau profesionale, locale sau generale);

- Factorii sociali: situația materială precară, lipsa de educație, rasa, zona de domiciliu sau mediul de proveniență (rural/urban), familie numeroasă;

- Alţi factori: indicii de carie cu valoare ridicată ai părinților/rudelor, prezența anomaliilor de structură a smalțului, vârsta înaintată a primei vizite la medicul dentist etc.

Pentru elaborarea unui algoritm pertinent al evaluării riscului la carie dentară trebuie luat în considerare fiecare factor de risc, precum şi importanţa (impactul) sau mai degrabă „contribuția“" acestuia la apariția de noi leziuni carioase.

Acest studiu şi-a propus dezvoltarea unui algoritm pentru riscul de carie dentară luând în considerare principalii factori de risc, precum şi impactul acestora.

\section{MATERIALE ŞI METODĂ}

Acest studiu are la bază o cercetare în stilul unei meta-analize în care au fost luate în considerare 128 de articole din bazele de date PubMed, EBSCO, Scirius, getCITED, WAME şi ResearchGATE. Articolele au fost selectate căutând cuvintele cheie: „caries“, „risk“ şi ,assessment“ în rezumatul (abstractul) acestora. Au fost eliminate articolele de tip „review“ sau meta-analiză.

$\mathrm{Au}$ fost contabilizaţi primii 5 factori de risc identificați pentru fiecare articol în parte, iar apoi au fost ordonați după aprecierea importanței. Specificând impactul fiecărui factor de risc, a fost definit algoritmul de calcul al riscului de carie.

\section{REZULTATE}

Factorii de risc descoperiți în aceste articole sunt redați în tabelul de mai jos:

TABELUL 1. Factorii de risc ai cariei dentare identificați prin algoritmul de căutare prezentat

\begin{tabular}{|l|c|}
\hline \multicolumn{1}{|c|}{ Factor de risc } & $\begin{array}{c}\text { Nr. de articole în care } \\
\text { a fost găsit }\end{array}$ \\
\hline Coloniile de Streptococ mutans & 18 \\
\hline Alimentația cariogenă & 24 \\
\hline Baseline-ul leziunilor de carie & 22 \\
\hline Parametrii salivari & 18 \\
\hline Absența fluorizărilor anterioare & 20 \\
\hline Calitatea precară a igienei orale & 22 \\
\hline Prezența anomaliilor de smalț & 8 \\
\hline Factorul social & 10 \\
\hline
\end{tabular}

Pentru fiecare dintre factorii de risc prezentați mai sus au fost stabilite praguri şi subvariabile pentru dezvoltarea unui algoritm de evaluare şi predicție a riscului de carie dentară. În ceea ce priveşte măsurarea datelor cu ajutorul chestionarului, s-a apelat la serviciile unui sociolog. Datele sunt prezentate în Tabelul 2.

\section{DEZVOLTAREA ALGORITMULUI}

Algoritmul a fost conceput în felul următor:

În primul rând, din datele prezentate în Tabelul 1 se poate observa faptul că, prin aproximare, unii factori sunt de două ori mai prezenți decât ceilalți. Ținând cont de această observație, am introdus un factor de corecție (FC) 2 doar pentru următorii factori de risc: coloniile de Streptococ mutans, alimentația cariogenă, baseline-ul de carie, parametrii salivari, absența fluorizărilor anterioare şi calitatea precară a igienei orale.

Apoi, urmărind Tabelul 2, se constată faptul că fiecare factor de risc a fost notat cu cifre romane I-VIII, iar subdiviziunile acestora cu litere $a, b, c$... . Fiecărui factor de risc sau de protecție i-a fost introdus un coeficient în funcție de poziția sa în scala de valori. Astfel, având în vedere că vorbim de un algoritm de risc, factorii de risc vor intra în ecuație cu un coeficient pozitiv, iar cei de protecție cu unul negativ. Prin urmare, ținând cont şi de factorul de corecție obținut în urma frecvenței cu care s-a detectat factorul în acest studiu, algoritmul este dictat de formula:

$\mathbf{R}=2 \mathrm{xI}+2 \mathrm{x}(\mathrm{IIa}+\mathrm{IIb})+2 \mathrm{x} \mathrm{III}+2 \times(\mathrm{IVa}+$ $\mathrm{IVb}+\mathrm{IVc})+2 \mathrm{x}$ V $+2 x \mathrm{VI}+\mathrm{VII}+\mathrm{VIIIa}+\mathrm{VIII} b$. 
TABELUL 2. Subvariabilele, pragurile valorice şi instrumentele de măsurare ale factorilor de risc ai cariei dentare. Se poate observa că pentru fiecare factor de risc/de protecție a fost atribuit şi un coeficient (în paranteză)

\begin{tabular}{|c|c|c|c|}
\hline Nr. & Factor de risc & Prag/subvariabilă & $\begin{array}{l}\text { Instrument de } \\
\text { măsurare }\end{array}$ \\
\hline 1 & $\begin{array}{l}\text { Coloniile de Streptococ } \\
\text { mutans }\end{array}$ & $10^{5} \mathrm{CFU} / \mathrm{ml}$ : sub (0) sau peste acest prag (1) & $\begin{array}{l}\text { Testul Saliva- } \\
\text { Check Mutans }\end{array}$ \\
\hline II & Alimentația cariogenă & $\begin{array}{l}\text { a. Consum de dulciuri: } \\
\text { - deloc (0) } \\
\text { - ocazional (1) } \\
\text { - o dată pe săptămână sau mai rar (2) } \\
\text { - de mai multe ori pe săptămână (3) } \\
\text { - zilnic (4) } \\
\text { b. Dulciuri preferate: } \\
\text { - ciocolată (1) } \\
\text { - băuturi cu zahăr (2) } \\
\text { - produse de patiserie (4) } \\
\text { - dulciuri lipicioase (caramele, jeleuri) (4) }\end{array}$ & Chestionar \\
\hline III & Base-line-ul & $\begin{array}{l}\text { DMFT: } 0(0), 1-2(1), 3-4(2), 4-8(3),>8(4) \\
\text { Punctele de reper au fost: } \\
\text { - molarii de } 6 \text { ani cariați (DMFT maxim 4) } \\
\text { - molarii de } 12 \text { ani cariați (DMFT maxim 8) } \\
\text { - dinți cariați de pe o întreagă hemiarcadă (DMFT > 8) }\end{array}$ & $\begin{array}{l}\text { Examen clinic }+ \\
\text { calculul indicelui } \\
\text { DMFT }\end{array}$ \\
\hline IV & Parametrii salivari & $\begin{array}{l}\text { a. Capacitatea tampon a salivei: normală (0)/scăzută }(1) / \text { foarte scăzută (2) } \\
\text { b. pH-ul salivar: }<6,4(2) ; 6,4-6,8(1) ; 6,8-7(0) ; 7-7,2(-1) ;>7,2(-2) \\
\text { c. Volumul secreției salivare măsurat timp de } 5 \text { minute: }<3,5 \mathrm{ml}(1) ; 3,5-5 \mathrm{ml} \\
(0) ;>5 \mathrm{ml}(-1) \text {. }\end{array}$ & $\begin{array}{l}\text { Testul Saliva- } \\
\text { Check Buffer }\end{array}$ \\
\hline $\mathrm{V}$ & $\begin{array}{l}\text { Absența fluorizărilor } \\
\text { anterioare }\end{array}$ & $\begin{array}{l}\text { S-au luat în calcul şi fluorizările anterioare, acestea constituind un factor de } \\
\text { protecție: fluorizări generale şi locale }(-3) \text {, doar generale }(-2) \text {, doar locale }(-1) \text {, } \\
\text { absența fluorizărilor }(0)\end{array}$ & Anamneză \\
\hline $\mathrm{VI}$ & $\begin{array}{l}\text { Calitatea precară a } \\
\text { igienei orale }\end{array}$ & $\begin{array}{l}\text { Indicele de igienă orală OHI-S: igienă excelentă/scor } 0 \text { (-1), bună/scor între } \\
0,1-1,2(0) \text {, moderată/scor între 1,3-3 (1) și slabă/scor între 3,1-6 (2) }\end{array}$ & $\begin{array}{l}\text { Examen clinic + } \\
\text { algoritm indice }\end{array}$ \\
\hline VII & $\begin{array}{l}\text { Prezența anomaliilor de } \\
\text { smalț }\end{array}$ & DA, la un dinte (1), 2-4 dinți (2), > 4 dinți (2)/NU (0) & Examen clinic \\
\hline VIII & Factorul social & $\begin{array}{l}\text { Numărul de membri ai familiei/numărul de camere a locuinței [raportul Mucii } \\
\text { (8)]: subunitar (0) sau supraunitar (1) } \\
\text { Venitul lunar al familiei: sub } 2 \text { salarii minime pe economie sau mai puțin (1), } \\
\text { peste dar până în } 1.000 \text { Eur (0), } 1.000-2.000 \text { Eur (-1), peste } 2.000 \text { Eur (-2) }\end{array}$ & $\begin{array}{l}\text { Chestionar + } \\
\text { anamneză }\end{array}$ \\
\hline
\end{tabular}

\section{DISCUȚII}

Algoritmul prezentat mai sus pentru riscul de carie dentară este o sumă a factorilor de risc, un factor reprezentând suma subvariabilelor sale, după caz, aplicându-se factorul de corecție 2 pentru primii 6 din listă. Practic fiecare termen al formulei (sumei) poate fi pozitiv sau negativ, caz în care riscul total va avea o valoare finală mai mare sau mai mică, în funcție de predominanța factorilor de risc $(+)$ sau de protecție (-). Formula este una empirică şi poate fi îmbunătăţită, dar plasează, totuşi, pacientul în situații diferite privind riscului de carie. Rezultatele pot fi şi negative sau 0 , cazuri în care se consideră că pacientul este lipsit de risc pentru carie dentară, în contextul nemodificării factorilor de risc/protecție, sau pozitive, situații în care, cu cât valoarea este mai mare, cu atât riscul poate fi, la rândul său, mai mare.

Deşi la prima vedere principiul după care s-a atribuit FC poate părea bizar (frecvența factorilor de risc în articolele selectate), există totuşi un raționament. Acesta se bazează pe ideea că atunci când un factor este abordat într-o proporție mai mare în fluxul principal de publicaţii, el prezintă mai multe argumente să fie implicat şi într-o proporție mai mare în riscul de carie, deoarece are în spate mai multe validări de ordin ştiinţific.

Sunt câteva sisteme pentru care s-au construit chiar şi software-uri pentru aprecierea riscului de carie dentară. Un astfel de sistem este Cariogram ${ }^{\mathrm{TM}}$. Acesta ține cont de experiența carioasă la momentul iniţial (baseline), boli generale asociate, felul dietei, frecvența dietei, cantitatea de placă dentară, prezența streptococilor, programe de fluorizare în antecedente, secreția de salivă şi capacitatea ei de tamponare. Coeficienții sunt introduşi doar sub formă de valori fixe $(0,1,2$ sau 3). Programul sugerează şi unele măsuri profilactice, în funcție de caz (9-11). 
Un alt sistem este PreViser ${ }^{\mathrm{TM}}$ în care riscul de carie (calculat conform scorului CAMBRA) are cinci categorii de încadrare: foarte scăzut, scăzut, moderat, crescut şi foarte crescut. Pe lângă riscul de carie mai există şi un raport clinic de evaluare, sugestii referitoare la igienizare şi planul de tratament, scorul de restaurație etc. (12).

Şi în România a fost dezvoltat un software bazat pe un raționament asemănător, dar mult mai simplu $(13,14)$. În ideea unor cercetări viitoare, cred că acest algoritm poate sta la baza designului şi modalității de calcul al unei noi versiuni a acestuia.

\section{BIBLIOGRAFIE}

1. Beighton D., Brailsford S., Samaranayake L.P., Brown J.P., Ping F.X., Grant-Mills D., Harris R., Lo E.C., Naidoo S., Ramos-Gomez F., Soo T.C., Burnside G., Pine C.M. A multi-country comparison of caries-associated microflora in demographically diverse children. Community Dent Health. 2004; 21(1 Suppl):96-101

2. Polk D.E., Weyant R.J., Manz M.C. Socioeconomic factors in adolescents' oral health: are they mediated by oral hygiene behaviors or preventive interventions? Community Dent Oral Epidemiol. 2010; 38(1):1-9

3. Reisine S.T., Psoter W. Socioeconomic status and selected behavioral determinants as risk factors for dental caries. J Dent Educ. 2001; 65(10):1009-1016

4. Harris R., Nicoll A.D., Adair P.M., Pine C.M. Risk factors for dental caries in young children: a systematic review of the literature. Community Dent Health. 2004; 21(1 Suppl):71-85

5. Funieru C., Twetman S., Funieru E., Dumitrache A., Sfeatcu R., Băicus C. Caries experience in schoolchildren in Bucharest, Romania: The PAROGIM Study. Journal of Public Health Dentistry 2014; 74(2):153-158

6. Funieru C., Țandără A., Cuculescu M., Ranga R., Comes A.C., Panaitescu E., Ivan L. Statistical correlations concerning dental and periodontal status and the level of education in oral health in pupils of Bucharest schools. Oral Health and Dental Management 2006 Sept. 3(17):11-17

7. Funieru C., Țandără A., Cuculescu M., Comes C., Panaitescu E., Dumitriu A., Dumitriu H.T. Knowledge of Bucharest schools pupils concerning oral health. Oral Health and Dental Management 2008 June; 2(7):19-24

\section{CONCLUZII}

Acest algoritm nu este foarte complex, dar modalitatea de culegere a datelor necesită o oarecare pregătire prealabilă. Înainte de a fi pus în practică, acest algoritm ar trebui validat printr-un studiu care să implice un lot consistent de pacienți. Acest studiu precum şi dezvoltarea unei noi versiuni de software pot reprezenta direcții viitoare de cercetare.

Mulțumiri. Doresc să mulțumesc companiei Colgate-Palmolive România pentru sprijinul acordat.

\section{Conflict of interest: none declared}

8. Mucii L.A., Hsieh C.C., Williams P.L., Dickman P.W., Björkman L., Pedersen N.L. Birthorder, sibship size, and housing density in relation to tooth loss and periodontal disease: A cohort study among Swedish twins. Am J Epidemiol 2004; 159:499-506

9. Petersson G.H., Bratthall D. Caries risk assessment: a comparison between the computer program ,Cariogram', dental hygienists and dentists. Swed Dent J. 2000; 24(4):129-37

10. Petersson G.H. Assessing caries risk using the Cariogram model. Swed Dent J Suppl. 2003;(158):1-65

11. Karabekiroğlu S., Ünlü N. Effectiveness of different preventive programs in cariogram parameters of young adults at high caries risk. Int J Dent. 2017; 2017:7189270

12. Doméjean S., Léger S., Rechmann P., White J.M., Featherstone J.D. How do dental students determine patients' caries risk level using the caries management by risk assessment (cambra) system? J Dent Educ. 2015 Mar; 79(3):278-85.

13. Funieru C., Funieru R. Caries Risk software - un nou instrument pentru aprecierea riscului de carie dentară la copii. Revista Română de Stomatologie 2015; 61(2):181-184

14. Funieru C., Răescu M., Popescu M.S., Dascalu I.T., Scrieciu M., Țuculină M.J. End-user study for Caries Risk software. Current Health Sciences Journal 2015; 41(suppl 7):48-51 